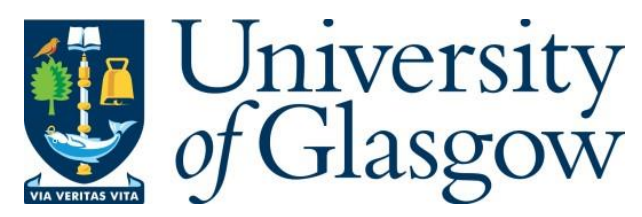

Soaita, A. M. (2015) The meaning of home in Romania: views from urban owneroccupiers. Journal of Housing and the Built Environment, 30(1), pp. 69-85.

There may be differences between this version and the published version. You are advised to consult the publisher's version if you wish to cite from it.

http://eprints.gla.ac.uk/147163/

Deposited on: 22 September 2017

Enlighten - Research publications by members of the University of Glasgow http://eprints.gla.ac.uk 
This paper was first published in:

Journal of Housing and the Built Environment, 2015, Volume 30, Issue 1, 69-85

DOI 10.1007/s10901-014-9396-3. All rights reserved (C) Springer Science+Business Media Dordrecht.

The final publication is available at Springer via

http://dx.doi.org/10.1007/s10901-014-9396-3

\title{
The meaning of home in Romania: views from urban owner-occupiers
}

\author{
Adriana Mihaela Soaita \\ Centre for Housing Research, University of St Andrews
}

\begin{abstract}
The post-communist privatisation of state flats to sitting tenants has transformed Romania into a nation of homeowners; yet its popularity appears perplexing given the poor quality of the stock and disappointing, given flat-owners' subsequent lack of action regarding home improvement. Conversely, self-builders' proactive agency moved them up the housing ladder. While this striking contrast draws attention to various structural conditions, which have constrained the former and enabled the latter, it also raises intriguing questions on residents' meanings of home. By interrogating 48 homeowners' narratives, this paper sustains the multilayered and multi-scalar meanings of home, which intertwine the socio-cultural territory of family and nation; the physical frame of one room or several dwellings; the emotional domain of object-memories; and the ontological realm epitomised by something as minimal as 'my bed'. Findings demonstrate that flat-owners and self-builders do not significantly differ in their meanings of home but detached houses rather than flats facilitate more fully their appropriation.
\end{abstract}

Keywords: communist housing; post-communist housing; Eastern Europe; homeownership; housing privatisation; meanings of home; Romania; self-build housing; suburbanisation. 


\section{Introduction}

Eastern European societies have been twice subjected to significant socioeconomic and political ructural changes, which have since been reshaping every domain of life, including housing. These predominantly agricultural and rural societies were rapidly industrialised but urbanised in a controlled and delayed approach (Kornai 1992). The political economy of communism had important implications for housing provision and access. Urban housing consisted predominantly of centrally planned large housing estates of small flats, which were built in insufficient numbers and allocated by municipalities or state enterprises. Benefitting from utility provision and urban location unlike other forms of housing, these flats were in high demand and signified social status (Sillince 1990). The post-communist privatisation of state housing was quantitatively significant in all countries but Bulgaria, where the state had built mainly for sale. The popularity of housing privatisation has resulted in 'super-ownership' eastern European countries (Lowe and Tsenkova 2003) having over 90 $\%$ of the housing stock privately held, with the exception of the Czech Republic and Poland. Yet, the state of decay of these housing estates continued throughout the 1990s. In order to take on their new responsibilities, flat-owners were challenged by incomplete or non-existent regulatory framework for condominium management and by widespread economic difficulties in financing the costs of utilities and repairs (Fearn 2004, Lowe and Tsenkova 2003).

After1989, states have withdrawn from housing provision and maintenance anticipating that private developers and owners will take on these new responsibilities. While speculative developers provided for the most affluent, strategies of self-building were reenergised in the rural landscapes across post-communist eastern Europe but they were especially salient in the suburbs of Albania, exYugoslavia, Romania, Slovenia and the Baltic States. Whether by illegal, informal or formal means of developing the land or financing and planning the construction, self-builders' agency has moved them up the housing ladder. It is important to acknowledge that very different forces at play have resulted in different outcomes across countries and social groups, nonetheless the contrast between the apparent compliance of most flat-owners in the communist estates and the proactive agency of selfbuilders raises important questions, not least regarding their meanings of home. Some questions 
regarding residents' challenges to home improvement in Romania were addressed elsewhere (Soaita 2012, 2013, Pascariu and Stanescu 2003), the latter will be explored in this paper.

By asking what are Romanian flat-owners' and self-builders' meanings of home and analysing the differences and similarities between these groups, the paper aims to contribute to an international scholarship, which remains fascinated by what makes the difference between a dwelling and a home but in which views from modern non Anglo-Saxon societies are underrepresented. The exploration of meanings and values, including those attached to home, should be critically articulated to the historical, political, geographical and socioeconomic contexts that continuously shape them (Bhaskar 1998, Richards 1990, Ronald 2008). This enhances the relevance of this paper since postcommunist societies have traversed unique changes in the housing field with consequential implications to how housing is provided and experienced. Additionally, Romania and other southeastern European post-communist states with agrarian pre-communist societies, centralised forms of communism and hesitant transitions, have been little explored (Tsenkova 2009). The paper proceeds with an outline of a large scholarship that conceptualised home within different perspectives of thought (Sect. 2). Section 3 contextualises the two environmentally and ideologically different housing types within the Romanian housing environment. After some methodological considerations (Sect. 4), Sect. 5 analyses residents' narratives, which render the multilayered meanings of home as experienced, made and imagined; as a recounted journey of self. Findings demonstrate that flatowners and self-builders do not significantly differ in their meanings of home but large, detached houses with gardens rather than flats facilitate more fully their appropriation. Section 6 concludes the paper outlining some policy implications.

\section{What is a home?}

The fascination with the subject of home has elicited a significant body of interdisciplinary scholarship in which modern non Anglo-Saxon societies are underrepresented (Ronald 2008; for reviewes see Blunt and Dowling 2006, Fox 2007, Mallett 2004, Moore 2000). Noticeably linked to particular worldviews, this scholarship has delineated three major perspectives on the understanding of home as: a site of core meanings and essential qualities (Moore 2000); a special kind of place 
(Easthope 2004); and a locale of intersecting ideologies (Ronald 2008). These perspectives, including reflection on the sparse literature on the meanings of home in post-communist societies, are presented next.

Home is a multidimensional and multi-scalar concept (Blunt and Dowling 2006) hence scholars attempted conceptualising those factors that distinguish it from a dwelling. For instance, Hayward (Smith 1994, p.31) 'described home as embracing a range of concepts such as family, social networks, self-identity, privacy, continuity, personalization, behaviour, the dwelling, and the childhood home'. Saunders (1989) saw home as essentially characterised by autonomy, privacy and (ontological) security. Fox (2007) unpacked the concept of home into five categories: a financial investment (for homeowners!); a physical structure; a territory of safety, security, familiarity and control; a representation of self-identity through feelings of attachment and practices of personalisation; and a socio-cultural unit of a family or nation. It became clear that meanings of home were differentially experienced by gender, age, ethnicity and class. Fox (2007) systematically reviewed meanings of home as heaven as well as woe. Feminist and youth studies viewed home as a domestic chore, a locale of concealed violence or isolation, a denial of self whereas legal and war studies focused on experiences of threatened homes (Kurst-Swanger and Petcosky 2003). Additional critical perspectives highlighted the crucial standpoints of disability and homelessness (Imrie 2004, Somerville 1992). Despite important contributions, it was argued that this perspective often conveyed a dis-embeddeded and fragmented concept of home (for instance Clapham 2005) and downgraded the socioeconomic, cultural and political context of home (for instance Ronald 2008). The first point was primarily addressed by conceptualising home as place.

Drawing on Heidegger's theory of place, Easthope (2004) defined home as a particularly important kind of place. Space is viewed as the locale where objects are situated whereas place is the enmeshment of objects, social relations and self into space. She further distinguished between 'thick' and 'thinned-out' places in terms of the degree to which one's identity enmeshes into space. Easthope (2004, p.135) saw home as holding 'considerable social, psychological and emotive meaning for individuals and for groups' which may be scaled from a bedroom to the nation. Likewise, Klis and Karsten (2009) conceived the meanings of residence as a continuum from space, defined by 
functionality; to place, defined by attachment; and finally to home, defined by intimacy and selfidentification. In their view, homemaking employs three key dimensions: the appropriation of the physical setting by means of 'thick' objects, including the physical structure; the performance of meaningful domestic activities (against meaningless tasks); and the occurrence of social engagement with significant others.

Similarly, Mallett (2004, p.69) argued for conceptualising home as a journey 'between the real and the ideal, the actual and remembered home'; this resonates with psychoanalytical and ethnographic views of home as a symbol of self, whose meanings change in relation to personal events (Gurney 1997, Marcus 2006). Practices of homemaking in one or multiple residences revealed a certain potential for cross-compensation between core meanings and key dimentions of home. For instance, personalisation of the physical setting compensated for inadequate social engagement; and inadequate features of the main residence were balanced by compensatory features of a second home (McIntyre et al. 2006). The conceptualisation of home as place has prompted a growing interest on the role of things in the assembly of home, such as family photographs (Rose 2003), room features (Cieraad 2006) or materialised money (Smith 2008). While responsive to residents' meanings and practices, this perspective rarely makes explicit their interdependencies to particular contexts of socioeconomic development, cultural and political values and institutions (Moore 2000).

Kemeny (1981) seminally emphasised the role of dominant ideologies in structuring housing systems in relation to other domains, particularly those of politics and social policies. Individualistic or collectivistic ideologies result in particular forms of housing provision, housing forms (dwellings and neighbourhood), housing quality and access via homeownership or social renting as well as in residents' meanings of home. It was argued that homeownership facilitated the full appropriation of home through feelings of attachment and being in control (Saunders 1989) but alternative critical views stressed that homeownership was unlikely to enhance homely feelings for those who struggled or fail to sustain high mortgage debts (Fox 2007). Ronald's emphasis (2008, p.43) on the dynamics between the ideology of homeownership and homeowners' ideologies - that is a dominant set of 'discursive practices of power and legitimation' versus residents' discourses and values pertaining to the consumption of housing - may help connecting the idea of home to its wider context. 
There is still a significant Anglo-Saxon and middle-class bias across empirical studies on the meanings of home (Ronald 2008). Within post-communist Europe where this scholarship is sparse, Mandic and Clapham (1996) showed a semantic division between the word dom (corresponding to 'home') and stanovanje ('dwelling') in Slovenian language. The former has the emotional connotation conveyed by the English home but it cannot be used in expressions of homeownership (which is the task of the latter) thus stripping the concept of dwelling-ownership of emotional power. Similarly, the Romanian language distinguishes between the noun casa and the adverb acasa. The noun casa denotes a physical dwelling (locuinta) - a house (casa) or flat (apartament) - as well as the sociocultural unit of family, household, and more metaphorically of nation. The Romanian adverb acasa (home) - as opposed to the English noun home(s) - addresses the spatial question 'where' (staying, heading or leaving home) and the modal question 'how' (longing for, feeling or being at home). In Romanian, therefore, a home cannot be formally owned but experienced and sensed.

Attwood's (2012) explorative study on the meaning of home in Russia reports that, despite similar semantic articulations between dwelling, home and homeownership, participants' key emphasis was that of formal ownership, particularly in terms of agency and control, although they enjoyed quasi-ownership rights prior to privatisation. Home as family and self-identity were other core meanings while overcrowding was experienced as a tolerable grievance. There were no references to the Anglo-Saxon meanings of financial investment, safety and privacy. Interestingly and similarly to Sweden (Kemeny 1981), home was constituted as a dual-locale of an urban flat and a rural weekend home. These two studies demonstrated that the meanings of home (Russia) and homeownership (Slovenia) were different from those reported in mainstream scholarship because different ideologies shaped very different bundle of rights and housing quality within and across tenures. However, given that the increasing scholarship on post-communist housing in eastern Europe was not concerned with meanings of home, this paper will remain necessarily explorative. It will try to uncover home's core meanings (rather than practices) with awareness for their socially constructed nature and without losing home unity as a special place. Firstly, the following section will position the two ideologically and environmentally very different housing types within the Romanian housing 
environment, focusing on those characteristics that are more likely to shape residents' meanings of home.

\section{The Romanian housing environment}

Romania has been twice subjected to significant structural changes in making and breaking the communist regime; their implications to housing have been by now well-documented (Clapham et al. 1996, Ronnas 1984, Kornai 1992, Lowe and Tsenkova 2003, Sillince 1990, Tsenkova 2009). Drawing on these and other analyses, I will pay particular attention to those housing characteristics that have most likely shaped residents' meanings of home. Since $75 \%$ of all current dwellings were built during communism (1946-1989) - and only 14 and $11 \%$ date to pre- and post-communist periods, respectively - legacies of the communist ideology are significant in terms of current housing conditions and residents' housing satisfaction (Soaita 2014).

The particularly strong drive for industrialisation and the political adoption of a centralised, non-reformist type of communist had resulted in extensive shortages and limited housing choice. The increase in urban population (from 23 to $55 \%$ ) was primarily accommodated in state housing clustered on large estates. Excluding the late 1940s nationalisation of urban dwellings, the only alternative form of housing was rural self-building. In the 1950s and 1960s self-building predominated (75\% of all new dwellings) whereas in the last two decades of communism, state housing prevailed ( $83 \%$, respectively). Currently 2.7 million flats, mostly urban ${ }^{\mathrm{i}}$ and 2.4 million selfbuilt houses, mostly rural were built over the communist period (NIS 2012). Comparable ownership rights applied to the 'personal'(private) and 'quasi-ownership'(state) tenures; the former was subjected to expropriation at any time while the latter was massively subsidised. Restrictions to one dwelling ownership applied to all households. Poor housing conditions, including widespread overcrowding, prevailed within urban and rural housing alike; rural houses were slightly larger than flats but lacked utility provision, which was the prerogative of urban flats.

It might be expected that meanings of home were less influenced by tenure -except for owners whose dwellings were forcibly nationalised or expropriated - but rather by housing conditions and location. Regarding meanings of homeownership, Mandic and Clapham (1996) evidenced this 
relationship in Slovenia where nonetheless housing choice was greater and shortages were lesser than in Romania. On a different note, the totalitarian ideology of communist tried to capture the personal realm of life and spawned an atomised society in which genuine social engagement resumed to close networks of family and friends, resulting in a home-centred lifestyle (Howard 2003, Kornai 1992, Ronnas 1984). If housing was in many ways central to the communist ideology, it lost its importance in the new political and economic order. Policies of commodification via restitutions of housing and land, privatisation to sitting tenants and more broadly, privatisation of the construction industry has changed the housing environment.

Housing privatisation proceeded in 1990 and was highly popular, raising the national homeownership rate from 64 to $98 \%$. In order to take on their new responsibilities, flat-owners were challenged by an inadequate regulatory framework for condominium management as well as by widespread economic difficulties in financing the costs of utilities and repairs (Fearn 2004). The postcommunist trajectories of these estates have been favoured by their dominance in urban markets and continuing socioeconomic mix, although they have lost their earlier symbolic status (Lowe and Tsenkova 2003). After 2000, stimulated by economic growth, raising utility costs and amended regulatory framework, resident action became noticeable. Residents prioritised the improvement of their flats in a drive for autonomy and privatism while not entirely disregarding the communal property. The challenges they faced in the management of their housing and their implications to policy were presented in-depth elsewhere (Soaita 2012). Equally, Romanian self-builders have embarked on a long-term enterprise in order to construct the autonomy and comfort offered by a detached house.

Besides housing shortages and a lack of housing finance, there were national specificities that have enabled self-building. The 1991 Land Law provided for in-kind restitution of agricultural land, recreating thus the fragmented land-ownership layouts of interwar reforms. The communist prohibition on the provision of detached housing throughout the 1980s has added pressure to the housing backlog. Economic depression during the 1990s, widespread economic informality and political illegitimacy were other key factors. Consequently, prior strategies of self-building were reactivated, resulting by 2012 in an almost equal number of new dwellings split between rural and 
urban areas, particularly salient in suburbs (NIS 2012). Housing conditions vary between and within rural/urban regimes and localities in terms of utility provision and construction quality, ranging from luxurious 'villas' to precarious dwellings of wattle-and-daub (25 percent of the housing stock in 2002). It can be estimated that suburban self-builders have contributed about $6 \%$ of the current housing stock, most of them enjoying the status of a new housing class (Hirt 2012). These relatively decommodified ways of accessing housing through privatisation of state flats, land and housing nationalisation, and varying degrees of housing informality have shaped a super-ownership society with nearly no mortgage debt (BNR 2007).

Two decades after the fall of communism, the urbanisation level has remained one of the lowest $(55 \%)$ while the homeownership rate has become the highest $(98 \%)$ in the EU. Within the EU, Romania was placed last in terms of underprovided rural utilities, second from last in terms of poverty rates and second in terms of overcrowding (EC 2011, Pascariu and Stanescu 2003, Tsenkova 2009). However, while data reveal critical constraints in the housing field, these do not tell how the idea of home is experienced by their occupiers. Chelcea (2003) documented the enduring effects that housing nationalisation had on co-residency arrangements between prior owners who were confiscated (part of) their homes and their tenants in Bucharest. Other studies documented tense political, legal and emotional struggles between prior owners and tenants in the redistribution of property rights via restitution (Zerillis 2006, Dawidson 2004, Stan, 2006). Disputes over ownership rights are likely to distress residents' meanings of home not only in nationalised housing, but also in forcibly expropriated dwellings for redevelopment or in the new condominiums where communal/private boundaries are still negotiated. As dwelling size is important for the activities in the home, it is important to note the unequal distribution of the Romanian housing stock. According to 2002 Census, a third of urban housing was overcrowded while $9 \%$ was vacant (of which $1 \%$ permanently and $8 \%$ seasonally). Overall, 10 million persons lived in overcrowded dwellings, of whom almost 3 million persons consumed less than $6 \mathrm{~m}^{2}$ habitable space ( 1 million in cities). The implications of unequal space consumption to housing policies were reported elsewhere (Soaita 2014) while its inference to residents' meanings of home will be shown in the empirical section. Data 
pertain to a wider research project, which looked in-depth and breathe to housing problems and residents responses in Romania (Soaita 2010).

\section{The city of Pitesti}

The city of Pitesti (170,000 inhabitants) was chosen for its portrayal of a typical 'socialist city' (Andrusz et al. 1996) in terms of massive post-1948 urban and industrial growth, and a high dominance of state housing. Among the eight large Romanian cities that grew faster than average during communism, seven were also strong new industrial centres (Ronnas 1984). While any of these would qualify, the research benefited from local knowledge as I lived and worked in Pitesti for 15 years. Due to the attraction of an above national average of foreign direct investment, Pitesti has become a successful second-tier city within the national network (Benedek 2006). Commencing in the early 1990s, suburbanisation doubled the built-up area of the city (Fig. 1) and by 2008 accounted for

Figure 1 The city of Pitesti

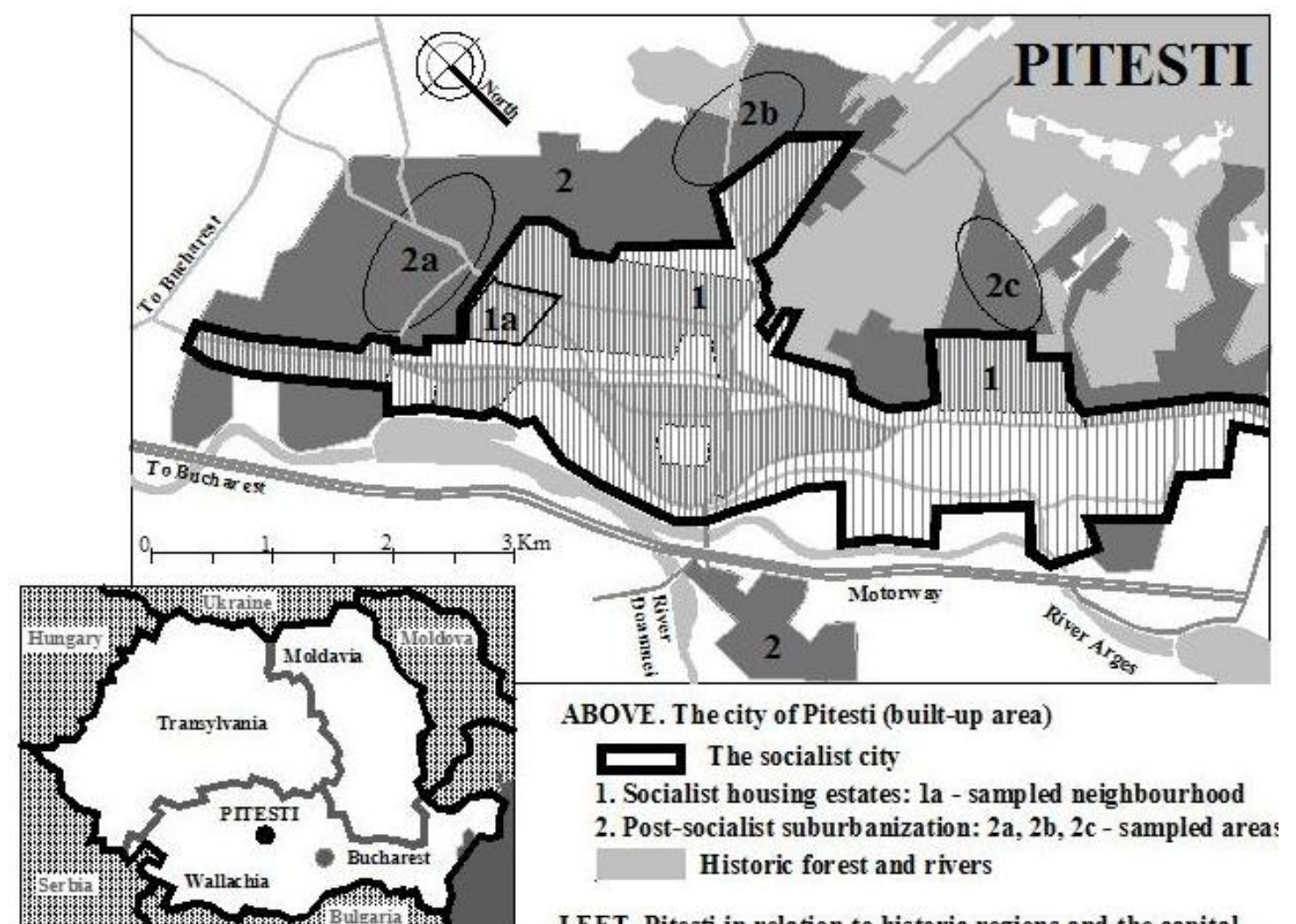

LEFT. Pitesti in relation to historic regions and the capital

Source: author's graphics 
Table 1 Quantitative sample distribution

\begin{tabular}{|c|c|c|c|c|c|c|c|c|c|c|c|}
\hline & \multicolumn{2}{|c|}{ Education (\%) } & \multicolumn{4}{|c|}{ Household composition } & \multicolumn{3}{|c|}{ Household economics (\%) } & \multicolumn{2}{|c|}{$\begin{array}{l}\text { Access to flat / land } \\
\text { ownership (\%) }\end{array}$} \\
\hline & $\begin{array}{l}\text { Up to } \\
\text { university }\end{array}$ & $\begin{array}{l}\text { University } \\
\text { and over }\end{array}$ & $\begin{array}{l}\text { Persons } \\
\text { (median) }\end{array}$ & $\begin{array}{l}\text { Single- } \\
\text { person } \\
(\%)\end{array}$ & $\begin{array}{l}\text { Extended } \\
\text { families } \\
(\%)\end{array}$ & $\begin{array}{l}\text { Age } \\
\text { (median) }\end{array}$ & $\begin{array}{l}\text { Not or just } \\
\text { enough to } \\
\text { live on }\end{array}$ & $\begin{array}{l}\text { Enough to live well } \\
\text { but without affording } \\
\text { expensive goods }\end{array}$ & $\begin{array}{l}\text { Enough to buy } \\
\text { most expensive } \\
\text { goods needed }\end{array}$ & $\begin{array}{l}\text { Restitution } \\
\text { policies }\end{array}$ & Market \\
\hline Blocks & 67 & 33 & 2 & 23 & 12 & 55 & 42 & 32 & 25 & 66 & 33 \\
\hline Houses & 34 & 66 & 4 & 6 & 29 & 48 & 11 & 34 & 53 & 14 & 86 \\
\hline $\begin{array}{l}\text { National } \\
\text { average* }\end{array}$ & 87 & 9 & 3 & 19 & 17 & - & 69 & 22 & 9 & - & - \\
\hline
\end{tabular}


about 6000 houses representing $6 \%$ of the housing stock, a small addition to the 54,000 communist flats (92\%). The approach of a 'typical neighbourhood' was considered for systematic quantitative sampling and in-depth interviewing. Finally, a typical communist housing estate of 5,100 flats and three representative suburban areas totalling about 1,000 plots were selected for analysis.

From September 2007 to June 2008, I collected a stratified sample of 150 and 100 questionnaires in the communist flats and suburban plots, respectively. Table 1 shows that the legacy of privileged allocation of state housing has persisted. Sampled flat-owners were better educated and more affluent than national averages, but self-builders were significantly more so than flat-owners. Considering the dominance of flats in a 'socialist city', it was not surprising that $80 \%$ of sampled self-builders had moved out from blocks. Dwelling sizes and market values across the samples were remarkably dissimilar. About two-third of sampled flats were under $50 \mathrm{~m}^{2}$ and three-quarters were one/two-roomed. Conversely, self-built houses were ostensibly large (64\% were five-roomed or more). The 2008 value of a one-/two-roomed flat was about $€ 30,000 / € 60,000$ (since then values have fallen by one-third). Rarely sold on, a median-sized plot $\left(800 \mathrm{~m}^{2}\right)$ with a median-sized house $\left(175 \mathrm{~m}^{2}\right.$, 5.5 rooms) was estimated at $€ 370,000$ (values have halved since then).

\section{Table 1}

Nested in the quantitative sample, a purposeful sample was selected for in-depth interviewing based on participants' socioeconomic characteristics and housing histories. Finally, 24 in-depth interviews in each housing type were conducted in participants' homes, involving 28 flat-owners and 32 self-builders. In each group there was about 50/50 split between female/males and first- /secondgeneration urbanites and participants' age ranged from 19 to 74 . In order to explore the meanings of home, participants were asked 'What do you understand by the word acasa?' and whether they felt acasa in every dwelling they had lived. Participants' narratives should thus be viewed as contemplative accounts of how home was experienced, made and remembered; as a recounted journey of self.

\section{Meanings of home: an empirical exploration}

Participants clearly highlighted the foremost meaning of home as 'family': 
When I think of home, I think of family! Practically, this is your entire universe as an individual! (38 male, self-builder).

Whether family was understood as nuclear or extended to close relatives and best friends; whether it was tangible or lost through divorce or bereavement, affectionate or partly dysfunctional; whether participants were married or single, the family was metaphorically ${ }^{\mathrm{ii}}$ seen as:

The most important thing in the world; Everything; The most sacred thing in the world; Our entire universe; The reason for life; The vital cell of life/society; Your own life; A single ALL; A small church; The country in small.

However, the intricacy of territorial negotiations within family transpired in situations of spatial or interpersonal stress. For instance, growing tensions between her mother and husband required one female participant (31, self-builder) to change the floor plans of her un-built house. Initially, an ensuite bedroom for the mother changed into a self-contained flat entered from the family living room only to be transformed again during the building process into a flat with external entrance but connected with the children's quarter by a door. The identification of home with family and family life may pertain to a one-home project, generally a nuclear family or to a dual-home project, which was evidenced by six married participants (of both genders and groups) and especially emphasised by a female participant (58, flat-owner, single):

Home is the place I feel most comfortable, where I am happy to return from work, from the city. However, our rural house is also my home but I can't say I am not at home in my flat! But there is home-HOME. Here, when I wake up in the morning and open my balcony door, I hear street dogs barking. There I see trees in blossom and flowers. I see the sunrise and the sunset! And my family is there! My parents have been always there, even if now it's only mom. There we used to meet as a family. Being single, here is "my home" but there is "our home".

Richards (1990) noticed the difficulty to separate the intertwined meanings of home. Likewise, the quotation above tells about home as a place of comfort, constructed in relation to family and the outside world (urban anomie versus idyllic countryside). Seven participants of both genders and 
groups perceived home - emotionally, socially and spatially - in opposition to the outside world in terms such as relaxing/stress, indulgent/unsympathetic, peace/battle, bunker/external, family/strangers, moon/sun and sacred/profane. However, for most participants home extended outwards to neighbouring places and included collective identities/geographies of the city, the region, and significantly more profound, the country - the latter emphasised by 5 flat-owners and 2 selfbuilders, arguably related to the nationalistic ideology of the Romanian communism (Chen 2007):

When I think home as place, I think this specific neighbourhood in Pitesti, not the whole city, a clearly delineated areal where I lived as a child! (38, male, self-builder)

When we crossed back the border, when we stepped again on the Romanian land, I give you my word I had that feeling of HOME! How shall I say? SUCH a feeling! (54 female, flatowner).

Whether inwards looking or expanding outwards, home as a locale of relaxation, understanding, peace and intimacy - that is of comfort and wellbeing - was clearly paramount. Another constellation of meanings, those of self-identity, continuity, familiarity and self-expression to which I will refer to as the emotional territory of home, were particularly emphasised. The emotional territory of home was contained with precedence in one dwelling, generally that of permanent residence (though 7 flatowners and 3 self-builders have constructed a balanced dual-locale attachment which included second homes). The quotation below brings forward a distinctive perception of the emotional territory of home as 'atmosphere', which evokes a familiar Dutch notion (Pennartz 1986):

Home is rather as an atmosphere... Home has been every dwelling we lived in because nothing has changed. I mean the atmosphere. The atmosphere has always been the same! Since we got married, all things surrounding us now, this lamp, this armchair... This painting, see, was bought in 1979 the day we got married, and so everything, all we have here is just as it has always been. That's why I never felt alienated when we moved places, to say "Oh, God, I changed everything and must take everything from the beginning"! My home has always been like that, the most beautiful, and we have always felt comfortable! (51 female, flat-owner). 
The 'atmosphere' of home, expressed by furnishing and 'objects-memory' ( 46 female, self-builder) these ranged from fridge magnets, family photos, display of gifts and figurines but also smell and thoughts - was especially emphasised by females. The more affluent flat-owners and self-builders talked with enthusiasm about their new interior designs, whether modern, traditional or frequently eclectic. Their narratives show a traditional and accepted gender division in the responsibility of homemaking. The traditional account of the man building the house and the woman making the home was especially obvious among self-builders and I had experienced it during my architectural practice by having to insist on my clients to involve their wives in design brief. Although the communist ideology praised the project of modernity, including through gender policies, the domestic life has resisted it the most. The personalisation of home by expressions of values and taste - remarkably, status was never implied - requires capacity of control. This sense of agency, of doing what one wants, was central to both adults and children in parental homes:

Sometimes, I can't wait to go away with friends but then, I can't wait to be back home. Ultimately, at home is the best. Because you can't be yourself anywhere else but at home! To be yourself, to do what you want without asking anyone for permission: "may I take this, may I use that?" Only at home I can do what I please! (19 female, block resident).

The exercise of agency in the personalisation of home creates a fluid association between the emotional territory and dwelling, which may require ownership of space. The quasi-ownership tenure of flats during communism permitted redecoration without consent being required, a freedom that had been taken up by all participants not necessarily because of poor condition but rather of established practices of 'symbolic cleaning' (51 female, flat-owner). Yet, formal ownership permitted greater control, such as remodelling layouts to fashion space fluidity - demolishing (non-structural) walls to merge the kitchen, hall and living room - of which flat-owners accounted with pride in lengthy narratives. Similarly, self-builders stressed a pride with their personalised layout and facades in a desire to negate the anomie of communist housing rather than making a social statement (analogous to other post-communist geographies, Hirt 2012). Remarkably, autonomy was clearly not seen as a quality of the home but essentially one of the dwelling. For self-builders autonomy was the second 
strongest reason to build - after the 'natural wish' for a detached house - whereas flat-owners struggled to increase their autonomy by installing individual utility metering (more detail in Soaita 2012, 2013).

This fluid association between the emotional territory of home and its physicality - 'home can be a flat, a house or just one room' (female 42, self-builder) - comes under stress when minimal physical requirements are absent, such as inadequate space. Participants recalled times when their appropriation of the meanings of home was frustrated by extreme overcrowding, which required complex management of the domestic timespace (Douglas 1991):

\footnotetext{
Nowadays, this flat means our home, my home. Especially since there are just the two of us, since the others had left. Before we were too overcrowded, too dependent on others, and others too dependent on us! You could not make your own schedule. It was no space! We had to eat in turns and sleep in turns! But now, it is home (74 female, flat-owner).
}

Interestingly, privacy is an explicit meaning of the Anglo-Saxon home, but in this study participants only implicitly mentioned it in terms of inside/outside separation as discussed before or in terms of family dependency as above. Similarly to Russia (Attwood 2012), this seems a consequence of the structural constrains of high-density housing and widespread overcrowding. It also suggests an ability to partially cross-compensate across the multilayered meanings of home or across multiple locales. The tragic experience of losing one's dwelling may forever disconnect home from any physical locale. Three flat-owners lived the traumatic experience of having had their homes forcibly demolished in the last years of communism. Two succeeded, however, to adapt and rebuild their home in the flats they were displaced to, and ironically offered to buy when housing privatisation was launched. They avoided long conversation as emotion broke through. But one participant was never able to recover his meanings of home after its forcibly communist demolition:

This flat is a shelter. Mentally, I have only felt at home in my detached house, privately owned. I still cannot say "home" here where I have lived for 20 years; I still go only "to my flat". I cannot say "home", in my head I still am, I still dream myself back in my house! Once, before I won back my land, I was factually in "my" garden. When I slowly raised my head and looked 
towards where my house used to be, oh, I saw it there, just as it was! So beautiful! Even now, I

cry. I cry. There is no "home" for me anymore! (71 male, flat-owner).

This participant spoke at length about his commitment and sacrifices in order to build his beautiful house, the enjoyment in dwelling in it, his struggle to resist demolition and post-1989 fight to get his land back. Regrettably, land restitution has not brought back lost feelings of home as he was unable to rebuild. Yet, the participant sold the land and succeeded to improve his family's economic situation while remaining, in Gurney's (1997) terms, an owner-occupier homeless.

I have so far considered some core meanings of home: foremost, that of family; second and closely intertwined, that of a place of comfort and wellbeing; third, that of an emotional territory entailing feelings of self-identity and practices of personalisation; fourth, that of control and agency, which requires actual or formal ownership of space. Fifth, although home is distinct from dwelling they remains associated. This association is generally fluid, allowing transferability to a new or multiple locales but it also can be/become inadequate or definitely disjoined. Six - the final theme to be presented next - participants emphasised home as providing them with a sense of (ontological) security. Before documenting this final theme, it is useful to reconstruct the unity of the concept by returning to the framework of home conceived as a continuum from space to a very special place.

Participants evidenced a continuum from a minimal to a maximal importance of home. Interestingly, no self-builder regarded home as just shelter, which was not surprising given that selfbuilding required an effort and determination that could only steam from 'thick' meanings of home complemented with socioeconomic capabilities. Two male participants (both in their 70s and flatowners) illustrated the minimal meaning of home: 'home is just a place to eat and rest'. There were four other flat-owners, males in their 50s for whom home 'thinned-out' to a comfortable, albeit homey space but who were missing either a rural home and/or more meaningful social engagement. This suggests that males rather than females may less likely be able to compensate across core meanings of home or to construct a dual-home locale. All other participants were dedicated homemakers engaged in family life (even if single) and space personalisation (according to their economic means), enjoying relaxation and comfort and exercising a sense of agency. Of these, five self-builders and one flat- 
owner explicitly connected home with a sense of ontological security. For instance, one male participant (72, self-builder) expressed with simplicity and concision a profound meaning of home as one's bed:

Home? The bed you were born, the bed you must die; you sleep on your pillow, as poor as you are, but your bed is yours and that's why you say is the best.

The ontological load of 'my bed' rests on home's essential meaning of abiding in peace and safety since lying down to rest exposes one's vulnerability. This participant's minimalist perspective also reflected a life that has lacked choice, he being by far the economically poorest and least-educated participant in this study. Living as a three generation household of five persons in a small two-roomed self-built bungalow, he was now assisting his grandson in building a small house on the same plot. Similarly, another participant (56, and not an affluent self-builder) talked suddenly with vigour when explaining his ontological meaning of home:

Of course everyone must have a home! Everyone who knows why one lives on this earth! If one hasn't, what could I say? Why do you live on the earth? What is your sense of life? You ask yourself "why was I born? Why have I come to live on this earth?" Just to make a shadow? Everything you are is in the home you own.

While owning one's home enables the expression of self, most self-builders expressed a sense of welfare security steamed from the autonomy and the wealth encapsulated in this housing type:

As this house represents material wealth, it gives me security, it makes me feel better as, whatever happens in our lives, I can sell it and we are safe, my children are safe, I am safe! (31 female)

The ontological symbolism of 'my bed' had an outdoor equivalent in the garden, seen as anchoring the home into the natural world. Participants highlighted the special significance of gardens in the constitution of home in recently urbanised societies, whether they had one or not: 
Strictly in an ontological sense, the metaphysical load of the concept of home is not that profound, that comprehensive in the urban as in the rural world. The rural home comprises land ownership, land and forests. In the city, home is only a necessity, a shelter whereas in the village, the home is linked to cosmos as seasons go by (54 male, flat-owner).

Look, I close my eyes and see my garden in three-four year time when trees and plants grow... Oh, I see it in autumn, summer, spring when trees blossom! I see my home connected to the natural world from which we were cut off for too long (55, male, self-builder).

The role of gardens as ontological anchors to the natural world - beyond places of relaxation and display - was captured in the popular metaphor of the new houses being presented as 'houses on the ground'. The ontological tie of home to nature's seasonal rhythms originated in rural livelihood where it acquired a special materiality in the customary veranda (prispa), a place of symbolic indoor/outdoor assembly (rather than a passage); this requisite has travelled to cities through a strong preference for flats with balconies (Ionescu 1971). Unsurprisingly for 10 flat-owners the ideal dwelling was a rural house and for a further 10 a suburban one (four refused to comment on what they could not achieve) whereas for 20 self-builders their ideal and actual dwelling coincided (four preferred larger or smaller houses). Finally, five participants (of both groups and genders) elaborated on the significant concept of parental home as an epistemological initiation to the world (distinct from the childhood home seen as a biographical stage by other two male participants):

In the Romanian language, the concept of parental home is exceptionally rich. It is HOME, a matrix, an archetype. Is where you open your eyes, where you shape your spirit, where you receive ideas from, and rites, and meanings. The word "home" comes second after "mother". Those meanings and ideas are still the lens I watch the world through (54 male, flat-owner).

\section{Concluding remarks}

By analysing Romanian flat-owners' and self-builders' meanings of home (rather than practices of homemaking), the paper aims to contribute to an international scholarship in which views from postcommunist societies are particularly sparse. By employing the conceptualisation of home as a site of 
core meanings, the analysis has shown that the foremost meaning of home was that of family. Besides family (1), the core meanings of home were grouped under five interrelated fields: (2) comfort and wellbeing; (3) an emotional territory entailing feelings of self-identity and practices of personalisation; (4) control and agency, which requires actual or formal ownership of space; (5) an association between the emotional territory of self and a physical locale; and (6) ontological security.

While findings largely support those found elsewhere, there are some remarkable differences. The meaning of home as a financial investment is yet not present despite market values being substantial in relation to incomes, which corroborates findings from Russia (Attwood, 2012). This is linked to wider constraints that inhibit downsizing or upsizing, such as lack of space, poor affordability and few housing alternatives. Findings also diverge from mainstream literature in that in this study, domestic privacy was not an explicit meaning of home, more likely due to widespread overcrowding. Likewise, autonomy (but also privacy in terms of soundproof walls and degree of detachment) seemed an essential quality of dwellings rather than homes, a distinction made possible by the semantic differentiation between the two as opposed to their English conflation. Additionally, this paper has conveyed unique perspectives of the concept of ontological security epitomised in something as minimal as one's bed, gardens as anchors to the natural world, or the epistemological matrix of the parental home. Self-builders viewed the building of their home similarly to Heidegger's (Fox, 2007) philosophical understanding of making sense of life, as a way of marking one's fingerprints into the world.

The conceptualisation of home as place permits a better understanding of the potential to cross-compensate across the multilayered and multi-scalar meanings of home. This was evidenced in the framework of a dual-home project, particularly intense for single-households, and a dual-locale particularly strong for flat-owners (an urban flat and a rural house as similarly reported in Sweden and Russia). While the association between space and the emotional territory of home was generally fluid, there were dwelling inadequacies that inhibited the development of a satisfying feeling of home; flatowners were clearly more affected, for instance in terms of lack of space and overcrowding, a strong preference for a different housing type and more rarely but exceptionally powerful, experiences of displacement. The change from quasi- to formal ownership through state privatisation experienced by 
18 flat-owner and 14 self-builder households did not affect meanings of home (including after probing) while it allowed the undertaking of substantial flat improvements or helped financing selfbuilding, both of which participants spoke with pride. Although participants inhabited very different housing types and their socioeconomic profiles differed significantly, they shared important sociocultural characteristics: commitment to traditional family values, strong rural ties, reduced spatial mobility and prolonged living in a flat. Findings demonstrate that flat-owners and self-builders do not significantly differ in their meanings of home but large, detached houses rather than undersized flats facilitate more fully their appropriation. This has several important policy consequences.

First, it is imperative to acknowledge that it is not an enduring tenant mindset which inhibits flat-owners in improving the physical conditions of their homes but rather complex externalities. Economic difficulties of some flat-owners, sluggish enforcement of condominium bylaws, private sector unresponsiveness and a general reluctance to organise collective action in most post-communist societies are key challenges to condominium management (the latter being well documented outside housing studies, for instance Howard 2003). Second, it is important to recognise that the communist housing estates are indeed homes rather than dwellings to a significant number of citizens. This is clearly beneficial for the future trajectory of these estates and should persuade public actors to sustain and encourage investment in order to increase their liveability and attractiveness. The mix of subsidisation, regulation and other enabling policies required to improve housing maintenance in these estates as well as the need for a sustained delivery of larger and affordable new dwellings in order to improve space standards were considered in-depth elsewhere (Soaita 2012, 2013). Thirdly, since anchoring home into the natural world is so fundamental to a sense of ontological security and given home's porosity towards the neighbourhood and city, this paper adds to other voices calling for environmentally greener cities. This could be achieved by relative modest green/open space refurbishment or innovative green roofs within estates as well as by protecting and expanding the existing networks of public gardens/squares within the city fabric. This explorative study focused on meanings of home in two particular housing types; however, a comprehensive understanding of the meaning of home in Romania requires additional and interdisciplinary perspectives in relation but not 
exclusive to disability, aging, ethnicity, homelessness, migration, past and present involuntary displacement, or unsafe homes.

\section{Acknowledgments}

I am grateful to the two anonymous referees for their thoughtful comments and to Mr Mike Birch who as always patiently proofread my manuscript.

\section{References}

Andrusz, G., Harloe, M. \& Szelenyi, I. (Eds.) (1996). Cities after Socialism: Urban and Regional Change and Conflict in Post-Socialist Societies. Oxford: Blackwell.

Attwood, L. (2012). Privatisation of housing in post-Soviet Russia: a new understanding of home? Europe-Asia Studies, 64(5), 903-28.

Benedek, J. (2006). Urban policy and urbanisation in the transition Romania. Romanian Review of Regional Studies, 2(1), 51-64.

Bhaskar, R. (1998). The Possibility of Naturalism: Philosophical Critique of the Contemporary Human Sciences. London: Routledge.

Blunt, A. \& Dowling, R. (2006). Home. Abington: Routledge.

BNR (2007). Evoluţia riscurilor populaţiei din perspectiva stabilităţii financiare. In BNR (Ed.) Analize, Bucharest: Romanian National Bank.

Chelcea, L. (2003). Domestic groups and the socialist state: housing nationalization and restitution in Romania. Comparative Studies in Society and History, 45(4), 714-40.

Chen, C. (2007). The Prospects for Liberal Nationalism in Post-Leninist States. University Park, PA: Pennsylvania State University Press.

Cieraad, I. (2006). At Home: An Anthropology of Domestic Space. Syracuse, New York: Syracuse University Press.

Clapham, D. (2005). The Meaning of Housing: A Pathway Approach. Bristol: The Policy Press.

Clapham, D., Hegedus, J., Kindrea, K., Tosics, I. \& Kay, H. (Eds.)(1996). Housing Privatization in Eastern Europe.' London: Greenwood Press. 
Dawidson, K.K. (2004). Conflicts of interest in the restitution and privatisation of housing since the fall of socialism: the case of Central Timisoara city - a problem of democracy? Europe-Asia Studies, 56(1), 119-41.

Douglas, M. (1991). The idea of a home: a kind of space. Social Research, 58(1), 287-307.

Easthope, H. (2004). A place called home. Housing, Theory and Society, 21(3), 128-38.

EC (2011). Key figures on Europe. Luxembourg: EC, Publications Office of the EU.

Fearn, J. (2004). Too Poor to Move, Too Poor to Stay: A Report on Housing in the Czech Republic, Hungary and Serbia. Budapest: OSI.

Fox, L. (2007). Conceptualising Home: Theories, Laws and Policies. Portland: Hart Publishers.

Gurney, C.M. (1997). "Half of me was satisfied": making sense of home through episodic ethnographies. Women's Studies International Forum, 20(3), 373-86.

Hirt, S.A. (2012). Iron Curtains: Gates, Suburbs and Privatization of Space in the Post-Socialist City Pondicherry: Wiley-Blackwell

Howard, M.M. (2003). The Weakness of Civil Society in Post-Communist Europe. Cambridge: Cambridge University Press.

Imrie, R. (2004). Housing quality, disability and domesticity. Housing Studies, 19(5), 685-90.

Ionescu, G. (1971). Arhitectura populara in Romania. Bucuresti: Editura Meridiane.

Kemeny, J. (1981). The Myth of Home Ownership: Private versus Public Choices in Housing Tenure. London: Routledge.

Klis, M. \& Karsten, L. (2009). Commuting partners, dual residences and the meaning of home. Journal of Environmental Psychology, 29(2), 235-45.

Kornai, J. (1992). The Socialist System: The Political Economy of Communism. Oxford: Oxford University Press.

Kurst-Swanger, K. \& Petcosky, J.L. (2003). Violence in the Home: Multidisciplinary Perspectives. Oxford: Oxford University Press.

Lowe, S. \& Tsenkova, S. (2003). Housing Change in East and Central Europe: Integration or Fragmentation? Ashgate: Aldershot. 
Mallett, S. (2004). Understanding home: a critical review of the literature. The Sociological Review, $52(1), 62-89$.

Mandic, S. \& Clapham, D. (1996). The meaning of home ownership in the transition from socialism: The example of Slovenia. Urban Studies, 33(1), 83-98.

Marcus, C.C. (2006). House As a Mirror of Self: Exploring the Deeper Meaning of Home. Berkeley: Nicholas-Hays.

McIntyre, N., Williams, D. \& McHugh, K. (Eds.) (2006). Multiple Dwelling and Tourism: Negotiating Place, Home and Identity. Wallingford: CABI Pub.

Moore, J. (2000). Placing home in context. Journal of Environmental Psychology, 20(27), 207-17.

NIS (2012). Census of population and dwellings 2002. Query public system RPL 1992 and 2002 In National Institute of Statistics Romania, Population and Households Census. Bucharest: NIS.

Pascariu, S. \& Stanescu, M. (2003). Management improvement and quality standard challenges: local government and housing in Romania. In M. Lux (Ed.) Housing Policy: An End or a New Beginning?: 245-91. Budapest: OSI.

Pennartz, P.J.J. (1986). Atmosphere at home: a qualitative approach. Journal of Environmental Psychology, 6(2), 135-53.

Richards, L. (1990). Nobody's Home: Dreams and Realities in a New Suburb Paperback Oxford: Oxford University Press.

Ronald, R. (2008). The Ideology of Home Ownership: Homeowner Societies and the Role of Housing Basingstoke: Palgrave Macmillan.

Ronnas, P. (1984). Urbanization in Romania: A Geography of Economic and Social Change Since Independence Stockholm: Stockholm School of Economics.

Rose, G. (2003). Family photographs and domestic spacings: a case study. Transactions of the Institute of British Geographers, 28:1, 5-18.

Saunders, P. (1989). The meaning of 'home' in contemporary English culture Housing Studies, 4(3), $177-92$.

Sillince, J. (1990). Housing Policies in Eastern Europe and Soviet Union. London: Routledge. 
Smith, S.G. (1994). The essential qualities of a home Journal of Environmental Psychology, 14, 3146.

Smith, S.J. (2008). Owner-occupation: at home with a hybrid of money and materials. Environment and Planning A, 40, 520-35.

Soaita, A.M. (2010). Unregulated Housing Privatism. PhD Thesis London: King's College London.

Soaita, A.M. (2012). Strategies for in-situ home improvement in Romanian large housing estates. Housing Studies, 27(7), 1008-30.

Soaita, A.M. (2013). Romanian suburban housing: home improvement through owner-building. Urban Studies, 50(10), 2084-101.

Soaita, A.M. (2014). Overcrowding and 'under-occupancy' in Romania: a case study of housing inequality. Environment and Planning A, 46(1), 203-221

Somerville, P. (1992). Homelessness and the meaning of home: rooflessness or rootlessness? International Journal of Urban and Regional Research, 16(4), 1992.

Stan, L. (2006). 'The roof over our heads: property restitution in Romania.' Journal of Communist Studies and Transition Politics, 22:2, 180-205.

Tsenkova, S. (2009). Housing Policy Reforms in Post-Socialist Europe: Lost in Transition. Heidelberg: Physica-Verlag.

Zerillis, F. (2006). Sentiments and/as property rights: restitution and conflict in postsocialist Romania. In M. Svasek (Ed.) Postsocialism: Politics and Emotions in Central and Eastern Europe: 7494. New York: Berghahn Books.

\footnotetext{
i 37 percent of the total housing stock and 72 percent of urban dwellings

ii Conversely, participants did not use metaphors to convey meanings of home. Most popular Romanian home' metaphors are variations of 'No place is like home' and 'The seven years from home' (in terms of home-acquired learning).
} 